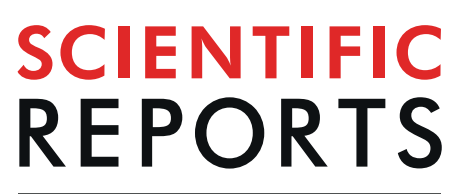

natureresearch

\title{
Diversity of Streptomyces spp. from mangrove forest of Sarawak (Malaysia) and screening of their antioxidant and cytotoxic activities
}

\author{
Jodi Woan-Fei Law ${ }^{1,2}$, Kok-Gan Chan $\mathbb{1}^{3,4^{*}}$, Ya-Wen He ${ }^{5}$, Tahir Mehmood Khan ${ }^{6,7}$, \\ Nurul-Syakima Ab Mutalib $\mathbb{1}^{8}{ }^{8}$, Bey-Hing Goh ${ }^{6,9 *}$ \& Learn-Han Lee ${ }^{2,5 *}$
}

Streptomycetes have been the center of attraction within scientific community owing to their capability to produce various bioactive compounds, for instance, with different antimicrobial, anticancer, and antioxidant properties. The search for novel Streptomyces spp. from underexplored area such as mangrove environment has been gaining attention since these microorganisms could produce pharmaceutically important metabolites. The aim of this study is to discover the diversity of Streptomyces spp. from mangrove in Sarawak and their bioactive potentials - in relation to antioxidant and cytotoxic activities. A total of 88 Streptomyces isolates were successfully recovered from the mangrove soil in Kuching, state of Sarawak, Malaysia. Phylogenetic analysis of all the isolates and their closely related type strains using 16S rRNA gene sequences resulted in 7 major clades in the phylogenetic tree reconstructed based on neighbour-joining algorithm. Of the 88 isolates, 18 isolates could be considered as potentially novel species according to the $16 \mathrm{~S}$ rRNA gene sequence and phylogenetic analyses. Preliminary bioactivity screening conducted on the potential novel Streptomyces isolates revealed significant antioxidant activity and notable cytotoxic effect against tested colon cancer cell lines (HCT-116, HT-29, Caco-2, and SW480), with greater cytotoxicity towards SW480 and HT-29 cells. This study highlighted that the Sarawak mangrove environment is a rich reservoir containing streptomycetes that could produce novel secondary metabolites with antioxidant and cytotoxic activities.

The remarkable contribution of microbes towards the area of drug discovery has ultimately improved human welfare around the world ${ }^{1}$. This is due to their capability in producing various useful natural products which later became the source of countless active ingredients of medicines ${ }^{2-4}$. In this regard, bacteria belonging to the genus Streptomyces have been acknowledged as the producers of many bioactive compounds, which makes them to be important microorganisms for drug discovery ${ }^{5,6}$. Streptomyces is documented as the major genus of the order Streptomycetales within the class Actinobacteria ${ }^{7-10}$.

Streptomycetes are complex filamentous Gram-positive bacteria with morphology resembles those of fungi ${ }^{11-13}$. The complexity of streptomycetes can be observed through their complicated developmental life cycle and their

${ }^{1}$ Institute of Biomedical and Pharmaceutical Sciences, Guangdong University of Technology, Guangzhou, 510006, P.R. China. ${ }^{2}$ Novel Bacteria and Drug Discovery (NBDD) Research Group, Microbiome and Bioresource Research Strength, Jeffrey Cheah School of Medicine and Health Sciences, Monash University Malaysia, 47500, Bandar Sunway, Selangor Darul Ehsan, Malaysia. ${ }^{3}$ Division of Genetics and Molecular Biology, Institute of Biological Sciences, Faculty of Science, University of Malaya, 50603, Kuala Lumpur, Malaysia. ${ }^{4}$ International Genome Centre, Jiangsu University, Zhenjiang, China. ${ }^{5}$ Microbial Quorum Sensing and Synthetic Biology, School of Life Sciences and Biotechnology, Shanghai Jiao Tong University, Dongchuan Road, \#800, Shanghai, 200240, China. ${ }^{6}$ Biofunctional Molecule Exploratory Research Group (BMEX), School of Pharmacy, Monash University Malaysia, 47500, Bandar Sunway, Selangor Darul Ehsan, Malaysia. ${ }^{7}$ Institute of Pharmaceutical Sciences (IPS), University of Veterinary \& Animal Sciences (UVAS) Out Fall Road, Lahore, Pakistan. ${ }^{8}$ UKM Medical Molecular Biology Institute (UMBI), UKM Medical Centre, Universiti Kebangsaan Malaysia, Kuala Lumpur, Malaysia. ${ }^{9} \mathrm{Health}$ and Well-being Cluster, Global Asia in the 21st Century (GA21) Platform, Monash University Malaysia, 47500, Bandar Sunway, Malaysia. *email: kokgan@um.edu.my; goh.bey.hing@monash.edu; lee.learn.han@monash.edu 
large genome size of more than $8 \mathrm{Mbp}$ with high $\mathrm{G}+\mathrm{C}$ content,often associated with their ability to prosper and survive in different environments ${ }^{13-16}$. Studies also revealed the presence of over 20 biosynthetic gene clusters related to biosynthesis of secondary metabolites in the large genome of streptomycetes. This may account for the production of structurally diverse bioactive secondary metabolites ${ }^{10,13,17}$. Due to the production of various useful compounds from streptomycetes including enzymes, pigments, and compounds possessing antimicrobial, anticancer, antioxidant, immunosuppressive and other important bioactivities ${ }^{17-21}$, these bacteria have been greatly explored for wide-range of applications. Currently, there are approximately 843 Streptomyces species isolated from different environments (www.bacterio.net) ${ }^{22}$.

Recently, researchers expressed interest in seeking novel streptomycetes from underexplored areas to increase the probabilities of discovering new compounds or therapeutic agents ${ }^{23}$. Mangrove environments are often underexplored but contains good resources for the isolation of novel streptomycetes ${ }^{24}$. It is known that the mangrove environments are constantly experiencing environmental variations such as changes in tidal gradient and salinity ${ }^{19,25}$. Despite these dynamic environmental factors, mangrove forests have always been home to various plants and animals. Instead, these unusual environmental changes may be the driving force for the development of microbial species diversity and adaptation of metabolic pathways that could be responsible to generate certain unique properties of microorganisms ${ }^{19,26}$. In this context, the study of streptomycetes from mangrove may provide a better prospect of uncovering novel Streptomyces spp. which may subsequently bring about the discovery of valuable bioactive molecules ${ }^{27,28}$.

Researchers are still actively studying the diversity of the microbial community in the phylum Actinobacteria originating from different environments and countries, often due to their ecological importance and biotechnological benefits ${ }^{29-31}$. However, there are limited number of studies reported on the diversity of streptomycetes especially in Malaysia and thus the population of this bacteria in Malaysia environments are poorly understood. Recent studies provide an increasing evidence on novel Streptomyces spp. isolated from Malaysia mangrove forests that could be valuable resource for antioxidant and anticancer compounds. For examples, crude extracts of Streptomyces antioxidans sp. nov. MUSC $164^{\mathrm{T}}$ and Streptomyces mangrovisoli sp. nov. MUSC $149^{\mathrm{T}}$ exhibited strong antioxidant activity ${ }^{23,32}$. Streptomyces malaysiense sp. nov. MUSC $136^{\mathrm{T}}$ discovered by Ser et al. ${ }^{33}$ was found to possess strong antioxidant activity and exhibit high cytotoxicity against colon cancer cell line HCT-116. Malaysia is categorized as a mangrove-rich country in Asia and many mangrove areas in Sarawak are mostly in pristine state $^{34,35}$. Therefore, this creates an important opportunity to explore the streptomycetes present in Sarawak mangrove forest together with their antioxidant and cytotoxic potentials.

Natural compounds have played an essential role in preventing or treating cancer, which is a major public health concern ${ }^{36-38}$. It is known that the development of cancer is linked to oxidative stress - a condition recognized by the imbalance between production of reactive oxygen species (ROS) and the competence to counteract the damage caused by ROS through antioxidant ${ }^{39,40}$. There is no doubt that researchers have been continuously looking for effective natural antioxidant and anticancer agents from natural sources including microorganisms ${ }^{41}$. For instance, a recent study conducted by Rao et al. ${ }^{42}$ reported the discovery of three pure compounds possessing antioxidant activity from a mangrove-derived Streptomyces coelicoflavus BC 01, namely 5-amino-2 -(6-(2-hydroxyethyl)-3-oxononyl) cyclohex-2-enone (BC 01_C1), 8-(aminomethyl)-7-hydroxy-1-(1-hydrox y-4-(hydroxylmethoxy)-2,3-dimethylbutyl)-2-methyl dodecahydro phenanthren-9(1H)-one (BC 01_C2), and 1-((E)-2-ethylhex-1-en-1-yl)2-((E)-2-ethylidenehexyl)cyclohexane-1,2-dicarboxylate (BC 01_C3). Apart from that, two novel bioactive compounds known as neoantimycins A and B were discovered from mangrove-derived Streptomyces antibioticus $\mathrm{H} 12-15^{43}$. The compounds showed cytotoxicity against human breast adenocarcinoma (MCF-7) cell line ( $\mathrm{IC}_{50}>50 \mu \mathrm{g} / \mathrm{mL}$ by both compounds), human glioblastoma (SF-268) cell line ( $\mathrm{IC}_{50} \mathrm{of} 33.6 \mu \mathrm{g} /$ $\mathrm{mL}$ by neoantimycin $\mathrm{A}$; $\mathrm{IC}_{50}$ of $41.6 \mu \mathrm{g} / \mathrm{mL}$ by neoantimycin $\left.\mathrm{B}\right)$, and human lung cancer (NCl-H460) cell line $\left(\mathrm{IC}_{50}>50 \mu \mathrm{g} / \mathrm{mL} \text { by both compounds }\right)^{43}$. Mangamuri et al. ${ }^{44}$ found a compound known as 2-methyl butyl propyl phthalate produced by mangrove-derived Streptomyces cheonanensis VUK-A, which exerted significant cytotoxic effect on human breast adenocarcinoma (MDA-MB-231), human cervical cancer (HeLa), human ovarian cyst adenocarcinoma (OAW42), and MCF-7 cell lines. In fact, the genus Streptomyces is a good source of chemotherapeutic agents verified through the discovery of several clinically important anticancer medicines such as mitomycin $\mathrm{C}^{45}$, dactinomycin ${ }^{46}$, doxorubicin (synonym adriamycin) $)^{47}$, and bleomycin ${ }^{13,48,49}$.

This study aims to explore the diversity of Streptomyces spp. from mangrove in Sarawak and screen them to determine potential sources for antioxidant and cytotoxic secondary metabolites. Sarawak mangrove forest mostly remains undisturbed, thus it is foreseen that this location could provide a rich supply of actinobacteria. To the best of our knowledge, this is the first report on the diversity and bioactive properties of streptomycetes from mangrove environments in Sarawak.

\section{Results}

Isolation of Streptomyces spp. Isolation of actinomycetes from environmental samples usually involve pre-treatments and the use of antibiotics as selective agents on culture media plates ${ }^{50,51}$. The study involved wet heat pre-treatment of sediments prior to isolation of streptomycetes. This is to reduce the number of undesirable bacteria present in the sediments that could often overrun media plates ${ }^{52,53}$. The isolation media were supplemented with cycloheximide to suppress the growth of fungi and nalidixic acid to suppress the growth of Gramnegative bacteria ${ }^{54,55}$.

A series of media plates were used for the isolation and characterization of streptomycetes in the present study. According to the typical cultural characteristics of a streptomycete (e.g. filamentous colonies with the development of dry, powdery-cottony aerial mycelium and non-fragmenting substrate mycelium) on media plate ${ }^{12,56,57}$, a total of 88 putative Streptomyces isolates were successfully isolated from 8 types of isolation media: ISP $2(n=3)$, ISP $5(n=8)$, ISP $6(n=24)$, ISP $7(n=9)$, SCA $(n=3)$, AIA $(n=5)$, NA $(n=22)$, and LB $(n=14)$. Based on the number of isolates recovered from each medium, it is noticeable that ISP 6 (peptone yeast extract 6 iron agar) was 
the most suitable medium for the isolation of Streptomyces in this study. This result is in agreement with others, which also recorded good growth of streptomycetes on ISP $6^{58-60}$. Mangrove soil samples were collected from 7 sites and labelled as KTTAS 1, KTTAS 2, KTTAS 3, KTTAS 4, KTTAS 5, KTTAS 6, and KTTAS 7 which contributes to $20,21,25,4,2,1$, and 15 isolates respectively, of the total number of isolates.

Diversity of Streptomyces isolates. These isolates were further identified and confirmed as Streptomyces sp. based on molecular analysis of $16 \mathrm{~S}$ rRNA gene sequences. The 16S rRNA gene sequences of these isolates were compared with related type strains retrieved from $\mathrm{DDBJ} / \mathrm{EMBL} / \mathrm{GenBank}$, and the results displayed percentages of pairwise sequence similarity ranged from $98.03 \%$ to $100 \%$. Their $16 \mathrm{~S}$ rRNA gene sequences were utilized for the reconstruction of neighbor-joining phylogenetic tree consisting 88 isolates of Streptomyces together with their closely related type strains to understand their taxonomic relationships (Fig. 1). Among these isolates, MUSC $1 \mathrm{~J}^{\mathrm{T}}$ and MUSC $93 \mathrm{~J}^{\mathrm{T}}$ have been confirmed as novel species. These two novel species, with the designated names Streptomyces monashensis sp. nov. MUSC $1 \mathrm{~J}^{\mathrm{T}}$ and Streptomyces colonosanans sp. nov. MUSC $93 \mathrm{~J}^{\mathrm{T}}$, were reported separately in earlier studies ${ }^{25,26}$.

Neighbour-joining phylogenetic tree constructed based on 16S rRNA gene sequences revealed 7 major clades, designated as Clade A-G; with 20 Streptomyces isolates were assigned to Clade A, 1 isolate was assigned to Clade B, 5 isolates assigned to Clade C, 4 isolates were assigned to Clade D, 29 isolates were assigned to Clade E, 3 isolates were assigned to Clade F, and 26 isolates were assigned to Clade G (Fig. 1).

The phylogenetic analysis demonstrated correlation between several isolates with type strains that possessed important bioactivities. In Clade B, S. monashensis MUSC $1 \mathrm{~J}^{\mathrm{T}}$ showed the highest percentage of 16S rRNA gene sequence similarity of $98.70 \%$ to Streptomyces corchorusii NBRC $13032^{\mathrm{T}}$. The phylogenetic analysis showed that S. monashensis MUSC $1 \mathrm{~J}^{\mathrm{T}}$ formed a monophyletic clade with type strain S. corchorusii NBRC $13032^{\mathrm{T}}$ at $99 \%$ bootstrap value (Fig. 1). Apparently, $S$. corchorusii $\mathrm{AUBN}_{1} / 7$, a strain isolated from marine sediment is capable of producing cytotoxic compounds such as resistomycin and tetracenomycin $\mathrm{D}^{61}$. Both pure compounds showed strong cytotoxicity against gastric adenocarcinoma (HMO2) and human liver cancer (HepG2) cell lines. The LC $_{50}$ values of resistomycin against $\mathrm{HMO} 2$ cells was $0.012 \mu \mathrm{g} / \mathrm{mL}$ and $\mathrm{HepG} 2$ cells was $0.015 \mu \mathrm{g} / \mathrm{mL}$, whilst the $\mathrm{LC}_{50}$ values of tetracenomycin D against $\mathrm{HMO} 2$ cells was $0.016 \mu \mathrm{g} / \mathrm{mL}$ and $\mathrm{HepG} 2$ cells was $0.021 \mu \mathrm{g} / \mathrm{mL}$.

In Clade C, S. colonosanans MUSC 93J ${ }^{\mathrm{T}}$ displayed the highest $16 \mathrm{~S}$ rRNA gene sequence similarity of $99.24 \%$ to type strain Streptomyces malachitofuscus NBRC $13059^{\mathrm{T}}$, forming a monophyletic clade at $52 \%$ bootstrap value (Fig. 1). Sajid et al. ${ }^{62}$ isolated Streptomyces sp. CTF9 with promising antifungal activity from soil samples of saline agricultural farmlands in Pakistan. This isolate was identified as S. malachitofuscus and it produced two active antifungal metabolites identified as phenylacetic acid and indolyl-1-lactic acid.

In addition, Streptomyces sp. MUM 133J, MUM 134J, MUM 140J, and MUM 178J exhibited highest percentage of 16S rRNA gene sequence similarity (98.06-98.65\%) to type strain Streptomyces fragilis NRRL $2424^{\mathrm{T}}$, forming a distinct phylogenetic clade as illustrated in Clade D (Fig. 1). S. fragilis is known as the producer of azaserine, which is a tumor-inhibiting antibiotic ${ }^{63,64}$.

For Clade E, 24 out of 29 Streptomyces isolates are closely related to type strain Streptomyces pluripotens MUSC $135^{\mathrm{T}}$, with highest percentage of $16 \mathrm{~S}$ rRNA gene sequence similarities ranged from $99.25 \%$ to $100 \%$. S. pluripotens MUSC $135^{\mathrm{T}}$ was first discovered by Lee et al. ${ }^{65}$ from mangrove soil collected at Tanjung Lumpur, Malaysia. The research group also reported the production of broad-spectrum bacteriocin from S. pluripotens that successfully inhibited methicillin-resistant Staphylococcus aureus. Furthermore, crude extract of S. pluripotens was also found to exhibit antioxidant and cytotoxic activities ${ }^{66,67}$. Two Streptomyces isolates, MUM 148aJ and MUM 148bJ exhibited highest percentage of $16 \mathrm{~S}$ rRNA gene sequence similarity to type strain Streptomyces griseoaurantiacus NBRC $15440^{\mathrm{T}}$ with $99.62 \%$ and $99.85 \%$ identities respectively, and they formed a distinct phylogenetic clade with S. griseoaurantiacus NBRC $15440^{\mathrm{T}}$ and Streptomyces jietaisiensis $\mathrm{FXJ}_{46^{\mathrm{T}}}$ at $99 \%$ bootstrap value, indicating high stability of the grouping (Fig. 1). Prashanthi et al. ${ }^{68}$ reported the isolation of $S$. griseoaurantiacus from soil samples that produced a yellow pigment which demonstrated in vitro anticancer activity against HeLa and HepG2 cell lines. The pigment exhibited strong cytotoxic effect towards HeLa cells with $\mathrm{IC}_{50}$ value of $1.8 \mu \mathrm{g} / \mathrm{mL}$ and HepG2 cells with $\mathrm{IC}_{50}$ value of $1.41 \mu \mathrm{g} / \mathrm{mL}$ after 72 hours treatment using MTT cell viability assay.

Streptomyces sp. MUM 109J, MUM $111 \mathrm{~J}$, and MUM 165 J exhibited highest percentage of 16S rRNA gene sequence similarity $(99.85-100 \%)$ to type strain Streptomyces qinglanensis $172205^{\mathrm{T}}$ and the phylogenetic analysis further supports that they are closely related to each other as observed in Clade F (Fig. 1). S. qinglanensis was first discovered and isolated from mangrove sediment at China by $\mathrm{Hu}$ et al. ${ }^{69}$.

As for Clade G, all Streptomyces isolates except Streptomyces sp. MUM 176J exhibited highest percentage of 16S rRNA gene sequence similarity (98.20-98.86\%) to type strain Streptomyces coeruleorubidus ISP $5145^{\mathrm{T}}$. Streptomyces sp. MUM 176 J showed highest percentage of $16 \mathrm{~S}$ rRNA gene sequence similarity of $98.25 \%$ to type strain Streptomyces coeruleoprunus NBRC $15400^{\mathrm{T}}$. The phylogenetic analysis showed that all 26 Streptomyces isolates formed a distinct phylogenetic clade with high bootstrap value of $99 \%$ (Fig. 1). However, these isolates appeared to be in a clade that was distinct from the type strains $S$. coeruleorubidus ISP $5145^{\mathrm{T}}$ and S. coeruleoprunus NBRC $15400^{\mathrm{T}}$. S. coeruleorubidus obtained from Egyptian soil was previously reported to produce antitumor/antibiotic activity by El-Sayed et al. ${ }^{70}$. The crude extract of this isolate was active in decreasing the survival of HepG2 cells and HCT-116 cells with $\mathrm{IC}_{50}$ values of $19.0 \mu \mathrm{g} / \mathrm{mL}$ and $26.8 \mu \mathrm{g} / \mathrm{mL}$ respectively.

Phylogenetic analysis based on the 16S rRNA gene sequences illustrated the relationship between these Streptomyces isolates. Taxonomic studies suggested that some isolates have the potential to be assigned as novel species. Besides, it can be deduced that the isolates in this study may produce interesting bioactive secondary metabolites since several of their closely related type strains exhibited bioactivities such as antioxidant, anticancer, and antimicrobial. Therefore, this led to the search of novel Streptomyces spp. and the exploration of their potential bioactivities. 


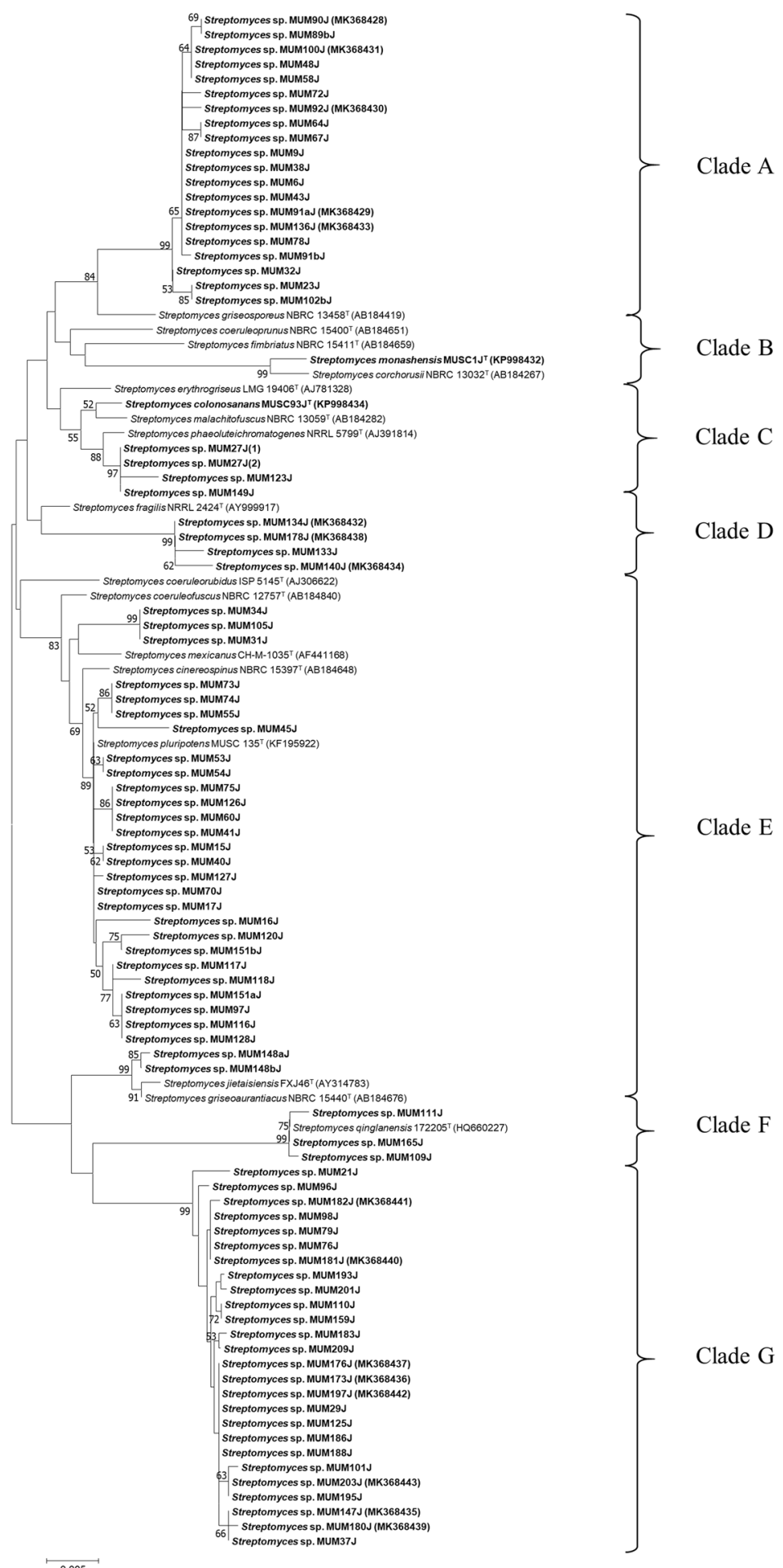

Figure 1. Neighbour-joining phylogenetic tree based on 16S rRNA gene sequences showing the relationship between the 88 Streptomyces sp. isolates and their closely related type strains. Bootstrap value based on 1000 resampled datasets are shown at branch nodes. Bar, 0.005 substitutions per site.

Diversity and phylogeny of potentially novel Streptomyces isolates. Detailed phylogenetic analysis and pairwise comparison of $16 \mathrm{~S}$ rRNA gene sequences of each Streptomyces isolate with its related type strains were conducted, and the results suggested that 18 out of the 88 Streptomyces isolates demonstrated high possibilities of novel species discovery. This taxonomic investigation of streptomycetes was in accordance with the approach performed by Lee et al. ${ }^{28}$. The phylogenetic relationship between the 18 potentially novel Streptomyces isolates and their closest related type strains is shown in Fig. 2. 


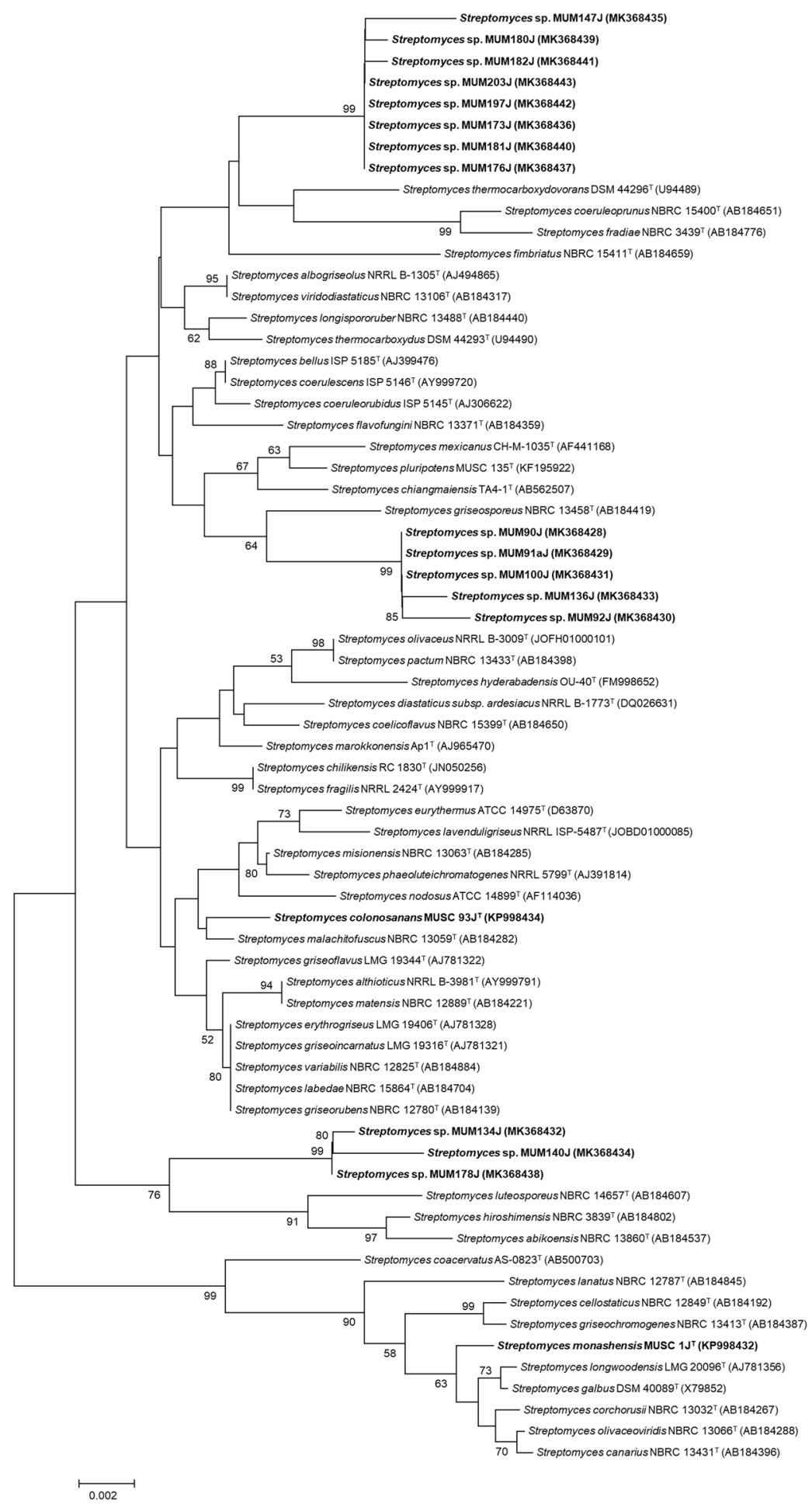

Figure 2. Neighbour-joining phylogenetic tree based on 16S rRNA gene sequences showing relationship between 18 potentially novel Streptomyces sp. and their closely related type strains. Bootstrap value based on 1000 resampled datasets are shown at branch nodes. Bar, 0.002 substitutions per site.

Notably, several type strains of Streptomyces listed in the neighbour-joining phylogenetic tree (Fig. 2) were first discovered as novel species originated from soil samples. For instances, Streptomyces thermocarboxydovorans DSM $44296^{\mathrm{T}}$ and Streptomyces thermocarboxydus DSM $44293^{\mathrm{T}}$ isolated from soil were first described and reported by Kim et al. ${ }^{71}$; Streptomyces hyderabadensis OU $-40^{\mathrm{T}}$ was first discovered by Reddy et al. ${ }^{72}$ from farm soil in Southern India; Streptomyces mexicanus $\mathrm{CH}-\mathrm{M}-1035^{\mathrm{T}}$ was first discovered by Petrosyan et al. ${ }^{73}$ from soil in Mexico; and Streptomyces pluripotens MUSC $135^{\mathrm{T}}$ was first isolated from mangrove soil in Malaysia and reported by Lee et al. ${ }^{65}$. Hence, it can be anticipated to unveil novel species from soils of the unexplored Sarawak mangrove forest. 


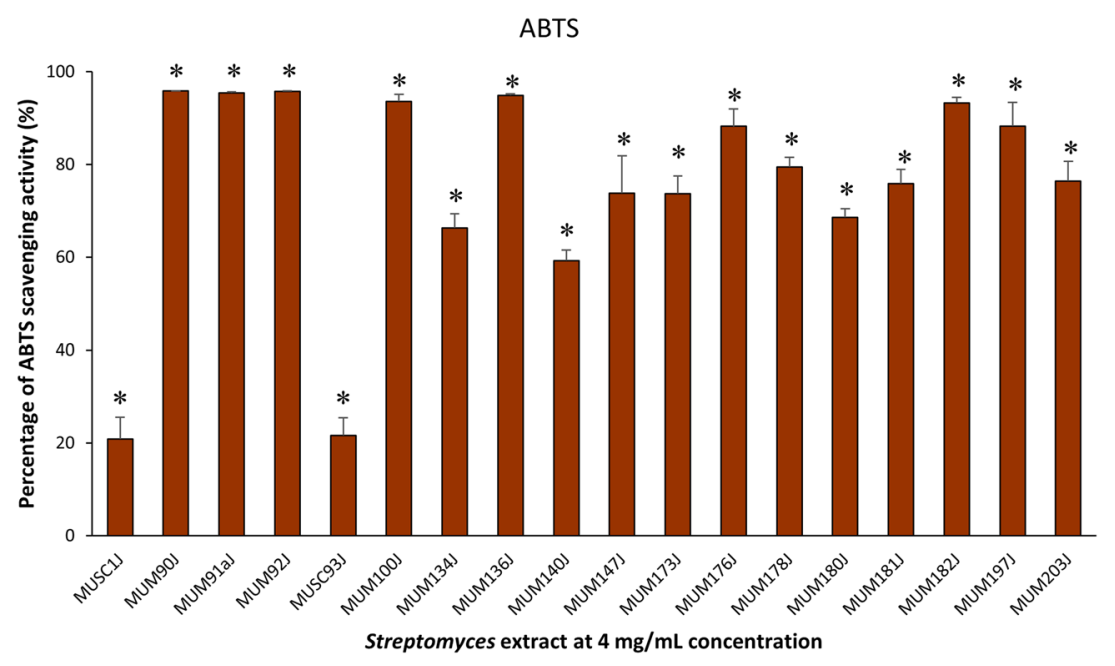

Figure 3. ABTS radical scavenging activity of extracts from potentially novel Streptomyces sp. isolates. Symbol $(*)$ indicates $\mathrm{p}<0.05$ significant difference between the extract and control (without extract).

Moreover, some of the closest related type strains were reported to exhibit bioactivities relating to antioxidant and antitumor/anticancer. For example, the crude methanolic extract of Streptomyces pluripotens exhibited significant antioxidative activity and was found to be cytotoxic against several human cancer cell lines such as colon cancer cell lines (HCT-116, HT-29, Caco-2, SW480), lung carcinoma cell line (A549), breast adenocarcinoma cell line (MCF-7), prostate cancer cell line (DU145), and cervical cancer cell line (Ca Ski) ${ }^{66}$. Balachandran et al. ${ }^{74}$ reported that Streptomyces galbus showed cytotoxicity towards A549 cell line and the active compound was found to be 2,3-dihydroxy-9,10-anthraquinone. Streptomyces griseorubens was previously reported to showed antitumor activity against HeLa cell line, human oral epidermoid cancer (KB) cell line and human hepatocarcinoma $\left(\right.$ SMMC7721) cell line ${ }^{75}$. Also, Reda $(2015)^{76}$ reported the production of L-glutaminase by Streptomyces canarius which had anticancer activity against HepG2, HeLa, and HCT-116 cells. These findings generally infer that the potentially novel Streptomyces isolates could be able to produce biologically active secondary metabolites such as antioxidant or anticancer agents.

Antioxidant activity of extracts from potentially novel Streptomyces isolates. Preliminary screening of antioxidant activity of the 18 potentially novel isolates was conducted using a high-throughput screening model involving the use of 96 -well plates. The outcomes of preliminary screening using ABTS, metal chelating, and SOD assays are presented in Figs 3-5 respectively. Overall, all tested extracts exerted statistically significant antioxidant activity via ABTS, metal chelating, and SOD assays. It can be observed that the extracts were capable of scavenging ABTS free radicals ranged from $20.87 \pm 4.69 \%$ to $95.82 \pm 0.05 \%$ at $4 \mathrm{mg} / \mathrm{mL}$ concentration (Fig. 3). For the metal chelating activity, the extracts exhibited significant activity ranged from $19.84 \pm 1.53 \%$ to $80.77 \pm 0.84 \%$ at $4 \mathrm{mg} / \mathrm{mL}$ concentration (Fig. 4). In this assay, antioxidative potential of the extracts was emphasized by prohibiting transition metals from promoting the generation of ROS ${ }^{33}$. Besides, the Streptomyces extracts demonstrated strong SOD-like activity ranged from $68.54 \pm 0.39 \%$ to $85.35 \pm 1.93 \%$ at the highest tested concentration of $2 \mathrm{mg} / \mathrm{mL}$ (Fig. 5). Most of the extracts showed high activity ( $>50 \%)$ in ABTS and SOD assays. However, only 3 extracts (MUSC $1 J^{\mathrm{T}}$, MUSC $93 \mathrm{~J}^{\mathrm{T}}$, and MUM 182J) showed more than $50 \%$ of metal chelating activity. Among the tested extracts, only MUM182J exhibited more than 50\% activity in all antioxidant assays. These results may suggest that most extracts are effective in scavenging ABTS free radicals and preventing generation of superoxide anion radicals but not as good at chelating metal ions.

Total phenolic content (TPC) of methanolic extracts and antioxidant activity. The TPC of extracts from the 18 potentially novel streptomycetes was evaluated. This analysis attempted to correlate the TPC and antioxidant activity across different Streptomyces methanolic extracts. The correlation coefficient $\left(R^{2}\right)$ was estimated to determine the relationship between the TPC and the antioxidant capacity of the 18 methanolic extracts (Fig. 6). The results revealed that the correlation coefficient between TPC and antioxidant capacity as analyzed by three different assays were very small; where the highest was observed in ABTS radical scavenging activity $\left(R^{2}=0.4003\right)$ (Fig. $\left.6 \mathrm{~A}\right)$, followed by SOD activity $\left(R^{2}=0.2343\right)$ (Fig. $\left.6 \mathrm{~B}\right)$, and metal chelating activity $\left(R^{2}=0.0084\right)$ (Fig. 6C).

Cytotoxic activity of extracts from potentially novel Streptomyces isolates. The present study examined the cytotoxic potential of extracts in four high-throughput models against human colon cancer cell lines: HCT-116, HT-29, Caco-2, and SW480, with extracts examined at $400 \mu \mathrm{g} / \mathrm{mL}$. The results illustrated that the extracts exhibited varying cytotoxicity against different colon cancer cell lines (Fig. 7). Of all the tested human colon cancer cell lines, the cytotoxic effect of the extracts was least notable against HCT-116 cell line, as only a total of 4 out of 18 Streptomyces extracts tested (MUSC 1J, MUSC 93J, MUM 176J, and MUM 


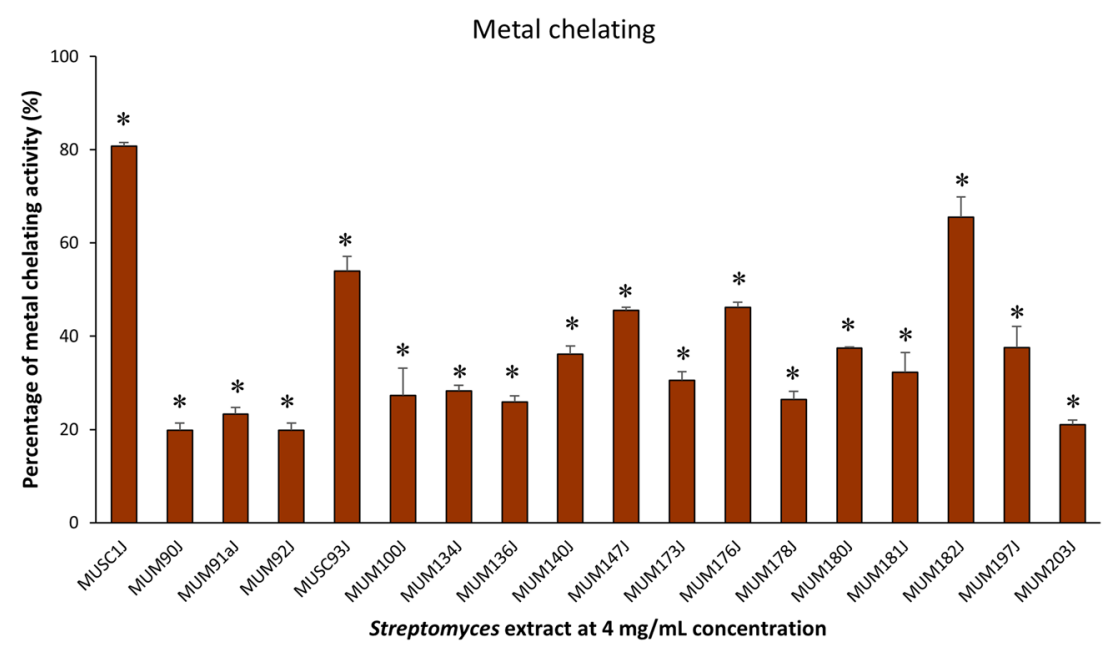

Figure 4. Metal chelating activity of extracts from potentially novel Streptomyces sp. isolates. Symbol (*) indicates $\mathrm{p}<0.05$ significant difference between the extract and control (without extract).

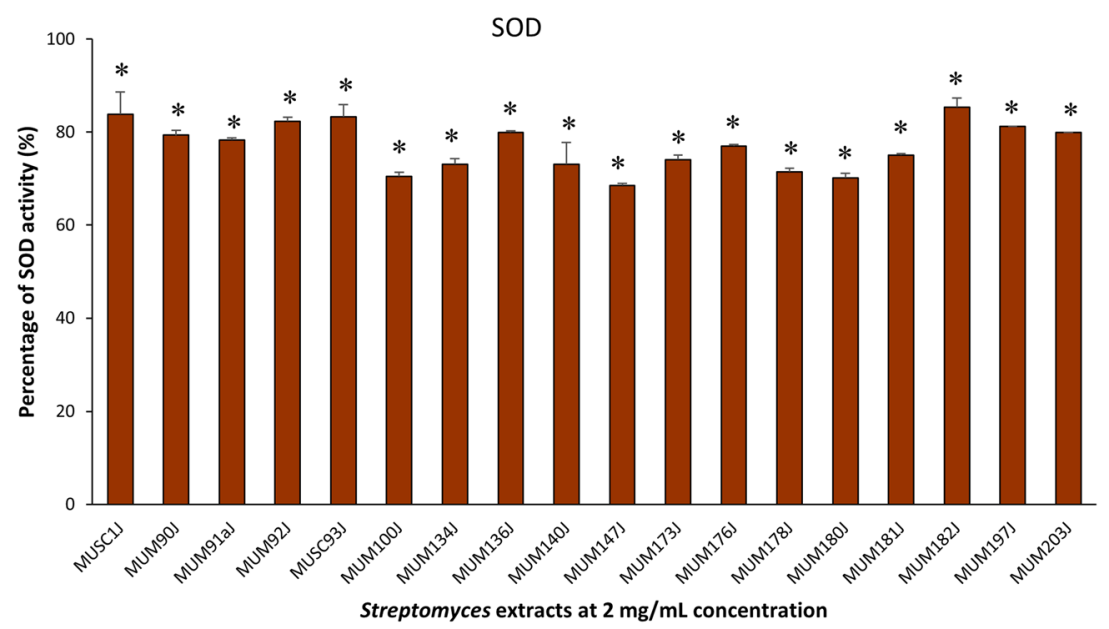

Figure 5. SOD-like activity of extracts from potentially novel Streptomyces sp. isolates. Symbol (*) indicates $\mathrm{p}<0.05$ significant difference between the extract and control (without extract).

$182 \mathrm{~J}$ ) exhibited significant cytotoxicity towards HCT-116 cells, with cell viability ranged from $82.3 \pm 5.3 \%$ to $86.9 \pm 5.0 \%$ (Fig. 7A). As for the Caco-2 cell line, 6 Streptomyces extracts (MUSC 93J, MUM 100J, MUM 147 J, MUM 176J, MUM 182 J, and MUM 197J) exhibited significant cytotoxic effect on Caco-2 cells with cell viability ranged from $74.8 \pm 2.6 \%$ to $87.4 \pm 5.3 \%$ (Fig. 7B). For SW480 cell line, 7 Streptomyces extracts (MUSC 1 J, MUSC 93J, MUM 100J, MUM 147J, MUM 176J, MUM 182J, and MUM 197 J) demonstrated significant cytotoxicity against the cells with cell viability as low as $32.8 \pm 7.7 \%$ to $87.4 \pm 3.6 \%$ (Fig. 7C), with Streptomyces sp. MUM 197J exhibited up to $60-70 \%$ reduction of cell viability. It seems that most of the extracts tested had demonstrated significant cytotoxicity on HT-29 cells as illustrated in Fig. 7D. The 10 out of 18 Streptomyces extracts tested (MUSC 1J, MUM 91aJ, MUM 92J, MUSC 93J, MUM 100J, MUM 147J, MUM 180J, MUM 181J, MUM 182J, and MUM 197J) showed significant cytotoxic activity against HT-29 cells with cell viability ranged from $50.7 \pm 0.9 \%$ to $89.4 \pm 1.7 \%$. Streptomyces sp. MUM 100J exhibited up to $40-50 \%$ reduction of cell viability.

\section{Discussion}

A total of 88 Streptomyces isolates were obtained from soil samples collected at 7 sites in this study. Majority of these soil samples collected from the sites consisted of rhizosphere soils. Except for site KTTAS6, where sediment samples were also collected. Previous studies have shown that mangrove rhizosphere soils are rich in streptomycetes $^{77-80}$. In the complex nature of mangrove rhizosphere environment, generation of root exudates could be the stimuli for species richness and chemical diversity of streptomycetes ${ }^{78,79}$. This rationalizes the higher number of Streptomyces isolates recovered from rhizosphere soil samples especially for those collected at sites KTTAS1, KTTAS2, and KTTAS3 as compared to that of sediment samples collected at site KTTAS6.

Findings of this study show that there is a high level of diversity within the genus Streptomyces present in mangrove of Sarawak. The isolates recovered from mangrove soil samples are related to various Streptomyces 

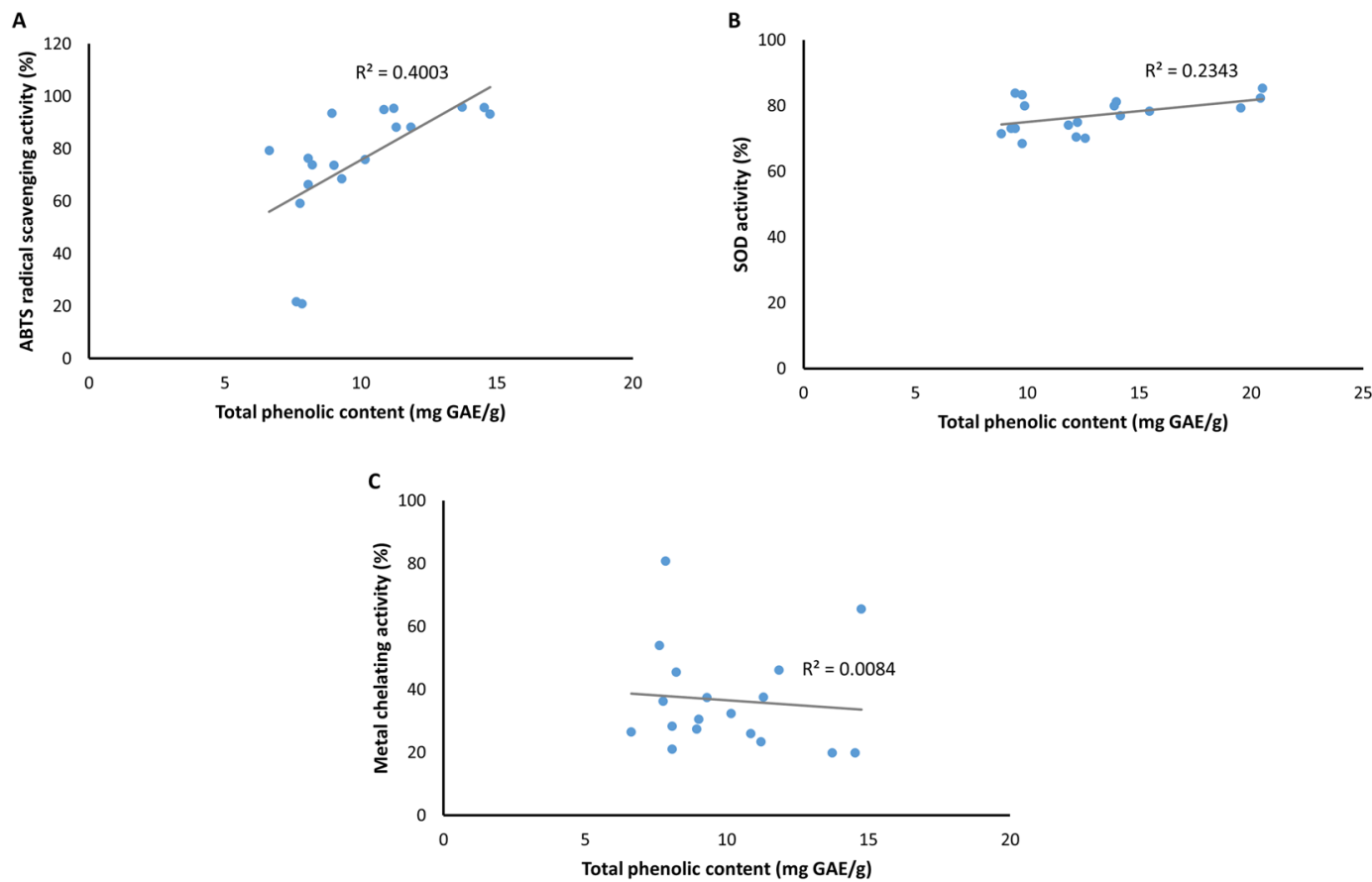

Figure 6. Correlation between total phenolic content and antioxidant capacity of 18 Streptomyces methanolic extracts. The relationship was observed in three different antioxidant assays: (A) ABTS, (B) SOD, and (C) metal chelating.

type strains, distributed into 7 major clades (Fig. 1). These type strains have been proven to produce useful bioactive compounds. For instances, $S$. corchorusii from marine sediment of Bay of Bengal in India (anticancer compounds) ${ }^{61}$ and S. malachitofuscus from soil of saline agricultural farmlands in Pakistan (antifungal compounds $)^{62}$. This subsequently prompted the investigation of novel Streptomyces spp., resulting in the discovery of 18 potentially novel Streptomyces isolates (Fig. 2). Of the 18 putative novel isolates, MUSC $1 J^{\mathrm{T} 25}$ and MUSC 93J ${ }^{\mathrm{T} 26}$ have been confirmed and reported as two distinct novel species through the application of polyphasic approach analyses. Streptomyces monashensis sp. nov. MUSC $1 \mathrm{~J}^{\mathrm{T}}$ was recognized by its significant antioxidative activity ${ }^{25}$; whilst Streptomyces colonosanans sp. nov. MUSC 93J ${ }^{\mathrm{T}}$ was recognized by its colon healing properties ${ }^{26}$.

By referring to the phylogenetic relationships of the potentially novel Streptomyces isolates and their closely related type strains, further literature search was conducted to obtain additional information on the type strains. It was found that some of these type strains have been previously reported to produce useful bioactive metabolites. Hence, the 18 potentially novel Streptomyces isolates were selected for further investigation of their antioxidant and cytotoxic potentials through a customized high-throughput screening using a 96-well microplate.

Antioxidants are crucial for overcoming health issues caused by oxidative stress including cancer, diabetes mellitus, atherosclerosis, and neurodegenerative disorders ${ }^{81-83}$. Numerous techniques have been established for the examination of antioxidant activity of natural compounds due to the many different mechanisms involved in antioxidants ${ }^{84}$. The use of a single assay might be insufficient to determine the antioxidant ability, thus preliminary screening of the antioxidant activity of the extracts in this study was conducted using three different in vitro antioxidant assays: ABTS, metal chelating and SOD. These assays operate based on different principles, for which, ABTS measures the ability of scavenging free radicals, metal chelating estimates the ability to chelate metal ions, and SOD determines the inhibition of superoxide anion radical generation ${ }^{85,86}$ (https://www.sigmaaldrich.com/ content/dam/sigma-aldrich/docs/Sigma/Datasheet/6/19160dat.pdf). Besides, ABTS, SOD and metal chelating assays are commonly used in many studies for the evaluation of antioxidant capacities of extracts. ABTS assay offers advantages such as rapid reaction with samples, additional flexibility in which it can work at varying $\mathrm{pH}$ levels as well as soluble in aqueous and organic solvents ${ }^{87}$. Meanwhile, metal chelating assay is conducted since chelation of metal ions is considered as one of the main mechanisms of antioxidant activity ${ }^{88}$. As for SOD assay, it is a simple experiment that can offer reproducible results ${ }^{89}$. Overall, the results of ABTS, SOD and metal chelating experiments demonstrated that the potentially novel Streptomyces isolates in this study generated significant antioxidant activity, and thus, the antioxidant traits of these isolates are worth to be further explored.

Phenolic compounds are recognized by their antioxidant activity and other bioactivities including anti-inflammatory, anti-microbial, and anti-allergenic ${ }^{90-92}$. As an initial attempt to determine whether phenolic compounds could be the contributors to the antioxidant activity produced by these streptomycetes, the TPC of Streptomyces methanolic extracts was evaluated to investigate the correlation of TPC and antioxidant activity. Based on the outcomes, it was unable to deduce that phenolic compounds were the major contributors to the antioxidant activity of these Streptomyces extracts due to the small correlation coefficient shown. Nonetheless, different samples of Streptomyces extracts were evaluated for the first time to establish the relationship between these two parameters. The results of this analysis could be limited by the small number of samples studied. Larger 

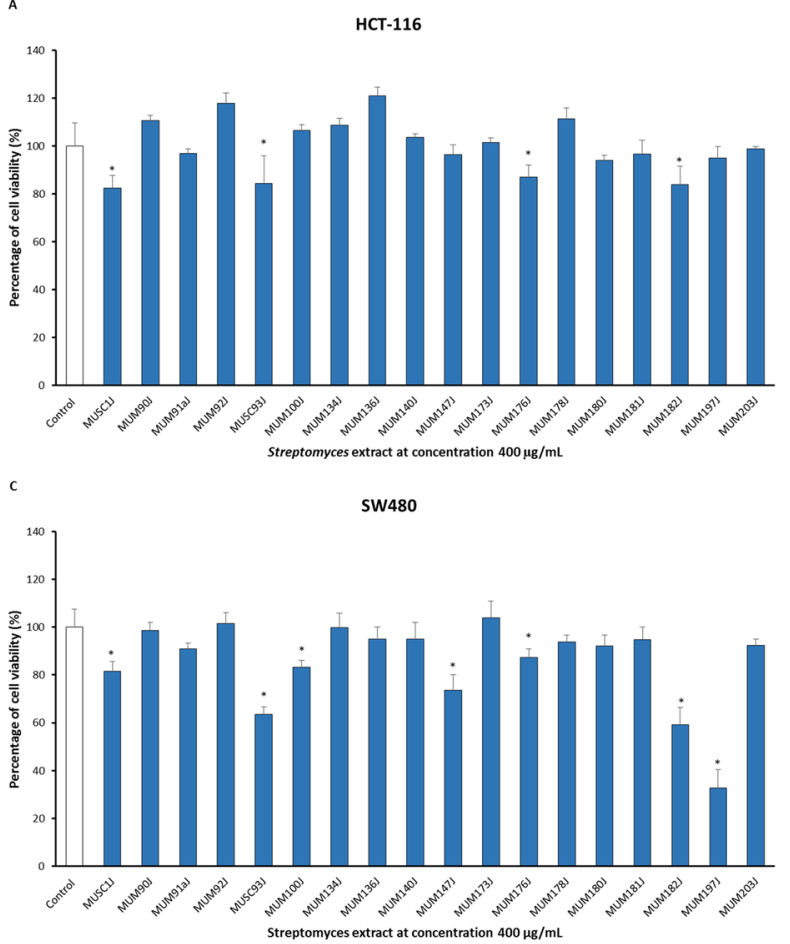
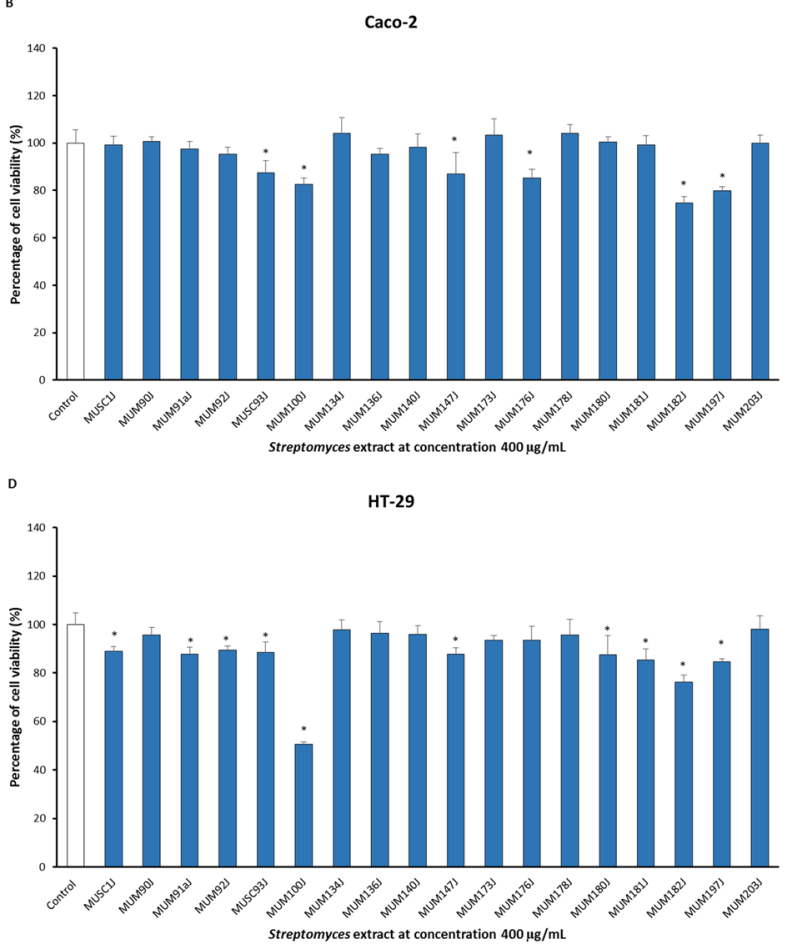

Figure 7. Cytotoxic activity of extracts from potentially novel Streptomyces isolates against colon cancer cell lines. The measurement of cell viability was done using MTT assay and the concentration of extract was $400 \mu \mathrm{g} /$ $\mathrm{mL}$. The graphs show cytotoxicity effect of the extracts against: (A) HCT-116, (B) Caco-2, (C) SW480, and (D) HT-29. All data are expressed as mean \pm standard deviation and significance level are set as 0.05 . Symbol $(*)$ indicates $\mathrm{p}<0.05$ significant difference between the cells treated with extract and control (without extract).

number of samples might be needed to further validate the relationship between these two parameters of the three antioxidant model systems. By increasing the sample size, there would be higher accuracy for the estimation of a correlation. In fact, the crude methanolic extracts may contain other compounds that are also accounted for their antioxidant activity. Perhaps in future studies, further experiments can be conducted for the determination of pure compound(s) responsible for the antioxidant activity exhibited by the methanolic extracts.

Globally, colorectal cancer ranked as the third most commonly diagnosed cancer ${ }^{40,93,94}$. Chemotherapy is one of the predominant methods to treat cancer, but there is limitation relating to the toxicities of the drugs used ${ }^{49,95}$. Hence, many ongoing efforts have been conducted by researchers around the world to search for effective chemotherapeutic agents in combating cancer. Human colon cancer cell lines with varied molecular characteristics (eg. HCT-116 cells contain wild type p53; HT-29, Caco-2, and SW480 contain mutated p53) were used as the panels in this study to examine the effectiveness of different extracts in inducing cytotoxicity against these cells ${ }^{96-98}$. The results of cytotoxic analysis revealed that majority of the Streptomyces extracts tested showed significant cytotoxicity against the colon cancer cells. The varying levels of cytotoxic activity observed could be due to the distinctive susceptibility or resistance of the colon cancer cell lines towards the extracts which contributed by their unique genetic makeup ${ }^{26}$.

In this study, rapid determination of bioactive isolates is established by the utilization of high-throughput screening systems which often involve performing various assays using 96 -well plates ${ }^{99,100}$. One of the examples of such study was conducted by Hong et al..$^{99}$ which involved five high-throughput screening models for the determination of antimicrobial, cell growth inhibition and enzymatic activities of over 2000 actinomycetes. The current findings unfolded many Streptomyces isolates exhibited at least one or both antioxidant and cytotoxic activities, thereby further supports that mangrove environments provide a rich source of bioactive streptomycetes.

Given the beneficial properties of streptomycetes can be offered towards mankind, it is encouraged that these microorganisms are introduced into genome programs in future studies. The advancement in next generation sequencing (NGS) technology offers high-throughput sequencing with more affordable price nowadays ${ }^{101}$. The genomic information obtained can be utilized for biosynthetic gene clusters mining for the determination of metabolite gene clusters capable of natural product biosynthesis, thus, exploiting the hidden potential of biosynthetic pathways ${ }^{101-105}$. Ultimately, the discovery of interesting compounds as potential drug leads is henceforth accomplishable. 


\section{Conclusion}

As a conclusion, the present study reveals the diversity of Streptomyces spp. from Sarawak mangrove based on a comprehensive genotypic and phylogenetic analyses. To our knowledge this is the first report on the diversity and bioactivities of streptomycetes from mangrove environment in Sarawak, East Malaysia. It is apparent that several of the Streptomyces isolates could merit novel species status, however, further investigation is required to confirm the novelty of the isolates. Other than the determination of possible novel species, the isolates demonstrated promising antioxidant and cytotoxic activities via a high-throughput bioactivity screening. This study has revealed untapped potential in Sarawak mangrove forest and it represents an invaluable source of streptomycetes that could be utilized for future bioprospecting studies. Additionally, the antioxidant and cytotoxic abilities presented by these mangrove-derived streptomycetes is a suggestive sign that they could be producing interesting bioactive compounds which may contribute to future drug discovery.

\section{Materials and Methods}

Environmental sampling. Collection of soil samples were conducted in June 2015 from mangrove forest at Kampung Trombol (Telaga Air) area of Kuching, state of Sarawak, Malaysia. Soil samples were obtained from 7 sites labelled as KTTAS 1 to KTTAS 7. At each site, three-sediment core samples were collected at a depth of approximately $20 \mathrm{~cm}$ (after removing $2-3 \mathrm{~cm}$ of surface soil) to make up one composite soil sample representing one site. The soil samples were placed into separate sterile $50 \mathrm{~mL}$ conical tubes using an aseptic metal trowel and stored in $-20^{\circ} \mathrm{C}$ freezer before transported to the laboratory ${ }^{106}$.

Selective isolation and purification of Streptomyces spp. Soil samples were air-dried for about 7 days. Air-dried soil samples were thoroughly mixed using a mortar and pestle, after that selective pretreatment was conducted using wet heat at $50^{\circ} \mathrm{C}$ for 15 minutes ${ }^{107,108}$. The pretreated soil samples were serially diluted $(1: 10 \mathrm{v} / \mathrm{v})$ with sterilized water for up to $10^{-4}$. For each of the $10^{-1}, 10^{-2}, 10^{-3}$, and $10^{-4}$ soil suspensions, $100 \mu \mathrm{L}$ of suspension was spread onto isolation media. Dilutions of suspensions were spread onto 11 different types of isolation media: ISP 2 (yeast malt agar), ISP 3 (oatmeal agar), ISP 4 (inorganic salt starch agar), ISP 5 (glycerol asparagine agar base), ISP 6 (peptone yeast extract 6 iron agar), ISP 7 (tyrosine agar base), Streptomyces agar (SA), starch casein agar (SCA), actinomycetes isolation agar (AIA), nutrient agar (NA), and Luria-Bertani agar (LB) ${ }^{28,109-111}$. All media were added with $50 \mathrm{mg} / \mathrm{L}$ of cycloheximide and $20 \mathrm{mg} / \mathrm{L}$ of nalidixic acid prior to experiment ${ }^{26}$. After the soil suspensions were spread onto the isolation media plates, the Petri dishes were incubated at $28^{\circ} \mathrm{C}$ for $1-4$ weeks. Streptomyces-like colonies with aerial mycelium and substrate mycelium features were selected and purified on ISP 2 medium. Maintenance of pure cultures included ISP 2 agar slants at $28^{\circ} \mathrm{C}$ and glycerol suspensions $(20 \%, \mathrm{v} / \mathrm{v})$ at $-20^{\circ} \mathrm{C}^{112}$.

Molecular identification of Streptomyces isolates. Genomic DNA extraction and PCR amplification of $16 S$ rRNA gene. Genomic DNA extraction was performed according to the procedure adapted from Hong et al. ${ }^{99}$. PCR amplification of $16 \mathrm{~S}$ rRNA gene was carried out in a final volume of $20 \mu \mathrm{L}$ using TurboCycler 2 (Blue-Ray Biotech, Taipei, Taiwan) based on protocol adapted from Lee et al. ${ }^{65}$, with highQu Taq DNA polymerase (Kraichtal, Germany), universal primers P27F_BGI (5'-AGAGTTTGATCCTGGCTCA-3') and P1492R_BGI ( $5^{\prime}$-GGTTACCTTGTTACGACTT-3'). The PCR cycling conditions were set as: initial denaturation at $95^{\circ} \mathrm{C}$ for 5 minutes, 35 cycles of $94^{\circ} \mathrm{C}$ for 50 seconds, $55^{\circ} \mathrm{C}$ for 1 minute, $72^{\circ} \mathrm{C}$ for 1 minute 30 seconds, and a final elongation at $72^{\circ} \mathrm{C}$ for 8 minutes.

Phylogenetic analysis of 16S rRNA gene sequences. The 16S rRNA gene sequences obtained were manually trimmed using BioEdit Sequence Alignment Editor Software and aligned with representative sequences of closely related type strains in the genus Streptomyces obtained from GenBank/EMBL/DDBJ databases using CLUSTAL-X software $^{113}$. The alignment was manually verified and adjusted before the reconstruction of phylogenetic tree. Phylogenetic tree was reconstructed with neighbour-joining algorithm using MEGA version 7.0 and the evolutionary distances for this algorithm were computed using Kimura's two-parameter model ${ }^{26,114}$. The stabilities of the resultant tree topologies were analyzed through bootstrap analysis based on 1000 resampling method of Felsenstein $(1985)^{115}$. Calculations of sequence similarity were performed by EzBioCloud server (http://www. ezbiocloud.net//) 116 .

Fermentation and preparation of Streptomyces crude extracts. Each isolate was grown in tryptone soya broth (TSB) (BioMerge, Malaysia) as seed medium for 14 days prior to fermentation process. Fermentation was carried out in sterilized $200 \mathrm{~mL}$ Han's Fermentation Media 1 (HFM1) (BioMerge, Malaysia) using a sterile $500 \mathrm{~mL}$ Erlenmeyer flask. The 14-day seed medium $(200 \mu \mathrm{L})$ was inoculated into the fermentation medium and cultured at $28^{\circ} \mathrm{C}, 200 \mathrm{rpm}$, for 10 days. Once fermentation was completed, the medium was subjected to centrifugation at $12000 \mathrm{~g}$ for 15 minutes, then the supernatant was filtered and collected. Freeze drying process was conducted on the clear filtrate, followed by extraction of freeze-dried sample using methanol for 72 hours and then re-extraction for twice at 24 hours intervals under same condition. The methanol containing extract was collected and concentrated by removing extracting solvent using a rotary vacuum evaporator at $40^{\circ} \mathrm{C}$. Final extract was suspended in dimethyl sulphoxide (DMSO) before proceeding to bioactivity screening ${ }^{26,33}$.

Bioactivities screening of Streptomyces crude extracts. Antioxidant activity screening assays. The 2,2'-azino-bis (3-ethylbenzothiazoline-6-sulphonic acid) (ABTS) assay was performed to determine the antioxidant potential of the Streptomyces extract. The procedure for ABTS assay was previously described by Law et al. ${ }^{26}$. Briefly, ABTS radical cation (ABTS.) was produced by the reaction between ABTS stock solution ( $7 \mathrm{mM})$ and potassium persulphate $(2.45 \mathrm{mM})$ for 24 hours. ABTS radical solution was added into the extracts (final concentration of $4 \mathrm{mg} / \mathrm{mL}$ in each well) preloaded in a 96-well microplate, with gallic acid as the positive control. The 
absorbance was measured at $743 \mathrm{~nm}$ using a microplate reader and the percentage of ABTS scavenging activity was calculated as follow ${ }^{117}$ :

Percentage of ABTS scavenging activity $(\%)=\frac{\text { Absorbance of control }- \text { Absorbance of sample }}{\text { Absorbance of control }} \times 100 \%$

Metal chelating activity of the Streptomyces extracts was investigated based on previously established method ${ }^{26,117} . \mathrm{FeSO}_{4}(2 \mathrm{mM}$ ) was added into extracts (final concentration of $4 \mathrm{mg} / \mathrm{mL}$ in each well) preloaded in a 96-well microplate and subsequently ferrozine $(5 \mathrm{mM})$ was added to start the reaction. The positive control included was EDTA. Absorbance was measured at $562 \mathrm{~nm}$ using a microplate reader and percentage of metal chelating activity was calculated as follows ${ }^{117}$ :

Percentage of metal chelating activity $(\%)=\frac{\text { Absorbance of control }- \text { Absorbance of sample }}{\text { Absorbance of control }} \times 100 \%$

Superoxide dismutase/superoxide anion scavenging (SOD) activity of the extracts was examined according to established method with the use of a commercially available SOD assay Kit-WST (Sigma-Aldrich) ${ }^{26,117}$. The reaction solutions were added into extracts (final concentration of $2 \mathrm{mg} / \mathrm{mL}$ ) preloaded in a 96-well microplate according to the manufacturer's instructions. The absorbance was measured at $450 \mathrm{~nm}$ and the percentage of SOD activity was calculated as follows ${ }^{26}$ :

$$
\text { Percentage of SOD activity }(\%)=\frac{((\text { Abs control blank } 1-\text { Abs buffer blank } 3)-(\text { Abs sample }- \text { Abs sample blank } 2))}{(\text { Abs control blank } 1-\text { Abs buffer blank } 3)} \times 100 \%
$$

Determination of total phenolic content. The total phenolic content in the extracts was analyzed using the Folin-Ciocalteu's reagent method according to the procedure described by Tan et al. ${ }^{117}$. Folin-Ciocalteu's reagent was diluted $1: 10 \mathrm{v} / \mathrm{v}$ with sterilized water prior to the experiment. The assay was conducted in a 96-well plate loaded with $10 \mu \mathrm{L}$ of extracts in respective wells. Then, $50 \mu \mathrm{L}$ of diluted Folin-Ciocalteu's reagent was added into each well containing the extract and incubated in the dark for 5 minutes at room temperature. After incubation, $7.5 \%$ sodium carbonate $(40 \mu \mathrm{L})$ was added into each well and incubated for 30 minutes at room temperature. Final absorbance was measured at $750 \mathrm{~nm}$ using a microplate reader and the data was expressed in gallic acid equivalents (GAEs).

Maintenance and growth condition of human derived cancer cell lines. The human colon cancer cell lines obtained for the current study were maintained in RPMI (Roswell Park Memorial Institute)-1640 (Gibco, United States) supplemented with $10 \%$ fetal bovine serum and $1 \mathrm{x}$ antibiotic-antimycotic (Gibco, United States) in a humidified incubator at $37^{\circ} \mathrm{C}$ with $5 \% \mathrm{CO}_{2}, 95 \%$ air ${ }^{26}$.

Cytotoxic activity screening using 3-(4,5-dimethylthazol-2yl)-2,5-diphenyl tetrazoliumbromide (MTT) assay. The human colon cancer cell lines tested in this study were HT-29, Caco-2, HCT116 and SW480. MTT assay was used for the investigation of cytotoxic activity the extracts according to protocol reported by Ser et al. ${ }^{6}$. Cells were seeded into a sterile 96 -well microplate at a density of $5 \times 10^{3}$ cells/well and allowed to adhere by overnight incubation at $37^{\circ} \mathrm{C}$ in humidified atmosphere with $5 \% \mathrm{CO}_{2}, 95 \%$ air. Extract was added to the cells with final concentration $400 \mu \mathrm{g} / \mathrm{mL}$ and further incubated for 72 hours prior to MTT assay. DMSO at $0.05 \%(\mathrm{v} / \mathrm{v})$ was included as negative control, while curcumin was included as positive control. MTT $(5 \mathrm{mg} / \mathrm{mL})$ (Sigma) was pipetted to each well and incubated for 4 hours. Then, the medium was gently aspirated and DMSO was added to dissolve the formazan crystals. The amount of formazan product was determined by measuring the absorbance at $570 \mathrm{~nm}$ (with $650 \mathrm{~nm}$ as reference wavelength) using a microplate reader. The percentage of cell viability was calculated according to the formula as shown below:

$$
\text { Percentage of cell viability }(\%)=\frac{\text { Absorbance of treated cells }}{\text { Absorbance of untreated cells }} \times 100 \%
$$

Statistical analysis. Antioxidant and cytotoxic screening assays in this study were conducted in quadruplicate. The data was stated as mean \pm standard deviation (SD). One-way analysis of variance (ANOVA) with subsequent Tukey's post hoc analysis was conducted using SPSS statistical analysis software version 22 to verify the significant differences between groups. A difference was considered statistically significant when $p \leq 0.05$.

Received: 30 May 2019; Accepted: 1 October 2019;

Published online: 03 December 2019

\section{References}

1. Demain, A. L. \& Sanchez, S. Microbial drug discovery: 80 years of progress. J. Antibiot. 62, 5 (2009).

2. Harvey, A. L. Natural products in drug discovery. Drug Discov. Today 13, 894-901, https://doi.org/10.1016/j.drudis.2008.07.004 (2008).

3. Gerwick, W. H. \& Fenner, A. M. Drug discovery from marine microbes. Microb. Ecol. 65, 800-806, https://doi.org/10.1007/s00248012-0169-9 (2013)

4. Ser, H.-L. et al. Draft genome sequence of mangrove-derived Streptomyces sp. MUSC 125 with antioxidant potential. Front. Microbiol. 7, 1470, https://doi.org/10.3389/fmicb.2016.01470 (2016). 
5. Azman, A.-S. et al. Antibacterial, anticancer and neuroprotective activities of rare Actinobacteria from mangrove forest soils. Indian J. Microbiol. 57, 177-187, https://doi.org/10.1007/s12088-016-0627-z (2017).

6. Law, J. W.-F. et al. A review on mangrove actinobacterial diversity: the roles of Streptomyces and novel species discovery. Prog. Microbes Mol. Biol. 1, a0000024 (2019).

7. Ludwig, W. et al. In Bergey's Manual ${ }^{\circledR}$ of Systematic Bacteriology (eds Michael Goodfellow et al.) 1-28 (Springer, 2012).

8. Law, J. W.-F. et al. The potential of Streptomyces as biocontrol agents against the rice blast fungus, Magnaporthe oryzae (Pyricularia oryzae). Front. Microbiol. 8, https://doi.org/10.3389/fmicb.2017.00003 (2017).

9. Kemung, H. M. et al. Streptomyces as a prominent resource of future anti-MRSA drugs. Front. Microbiol. 9, 2221, https://doi. org/10.3389/fmicb.2018.02221 (2018).

10. Ser, H.-L. et al. Complete genome of mangrove-derived anti-MRSA streptomycete, Streptomyces pluripotens MUSC $135^{\mathrm{T}}$. Prog. Microbes Mol. Biol. 1, a0000004 (2018).

11. Flärdh, K. \& Buttner, M. J. Streptomyces morphogenetics: dissecting differentiation in a filamentous bacterium. Nat. Rev. Microbiol. 7, 36, https://doi.org/10.1038/nrmicro1968 (2009).

12. Hasani, A., Kariminik, A. \& Issazadeh, K. Streptomycetes: characteristics and their antimicrobial activities. IJABBR 2, 63-75 (2014).

13. Ser, H.-L. et al. Focused review: cytotoxic and antioxidant potentials of mangrove-derived Streptomyces. Front. Microbiol. 8, 2065, https://doi.org/10.3389/fmicb.2017.02065 (2017).

14. Law, J. W.-F., Tan, K.-X., Wong, S. H., Ab Mutalib, N.-S. \& Lee, L.-H. Taxonomic and characterization methods of Streptomyces: a review. Prog. Microbes Mol. Biol. 1, a0000009 (2018).

15. Ser, H.-L. et al. Whole genome sequence of Streptomyces humi strain MUSC $119^{\mathrm{T}}$ isolated from intertidal soil. Prog. Drug Discov. Biomed. Sci. 2, a0000020 (2019).

16. Cheah, Y. K., Lee, L. H., Chieng, C. Y. C. \& Wong, V. L. C. M. Isolation, identification and screening of actinobacteria in volcanic soil of deception island (the Antarctic) for antimicrobial metabolites. Pol. Polar Res. 36, 67-78, https://doi.org/10.1515/ popore-2015-0001 (2015)

17. Nett, M., Ikeda, H. \& Moore, B. S. Genomic basis for natural product biosynthetic diversity in the actinomycetes. Nat. Prod. Rep. 26, 1362-1384, https://doi.org/10.1039/b817069j (2009).

18. Charkoudian, L. K., Fitzgerald, J. T., Khosla, C. \& Champlin, A. In living color: bacterial pigments as an untapped resource in the classroom and beyond. PLoS Biol. 8, e1000510, https://doi.org/10.1371/journal.pbio.1000510 (2010).

19. Sathya, R. \& Ushadevi, T. Industrially important enzymes producing Streptomyces species from mangrove sediments. Int. J. Pharm. Pharm. Sci. 6, 233-237 (2014).

20. Ser, H.-L. et al. Fermentation conditions that affect clavulanic acid production in Streptomyces clavuligerus: a systematic review. Front. Microbiol. 7, 522, https://doi.org/10.3389/fmicb.2016.00522 (2016).

21. Ser, H.-L. et al. Genome sequence of Streptomyces gilvigriseus MUSC $26^{\mathrm{T}}$ isolated from mangrove forest. Braz. J. Microbiol. 49, 207-209, https://doi.org/10.1016/j.bjm.2017.04.012 (2018).

22. Parte, A. C. LPSN-List of prokaryotic names with standing in nomenclature (bacterio. net), 20 years on. Int. J. Syst. Evol. Microbiol. 68, 1825-1829, https://doi.org/10.1099/ijsem.0.002786 (2018).

23. Ser, H.-L. et al. Streptomyces antioxidans sp. nov., a novel mangrove soil actinobacterium with antioxidative and neuroprotective potentials. Front. Microbiol. 7, https://doi.org/10.3389/fmicb.2016.00899 (2016)

24. Rajkumar, J., Swarnakumar, N., Sivakumar, K., Thangaradjou, T. \& Kannan, L. Actinobacterial diversity of mangrove environment of the Bhitherkanika mangroves, east coast of Orissa, India. IJSRP 2, 1-6 (2012).

25. Law, J. W.-F. et al. Streptomyces monashensis sp. nov., a novel mangrove soil actinobacterium from East Malaysia with antioxidative potential. Sci. Rep. 9, 3056, https://doi.org/10.1038/s41598-019-39592-6 (2019).

26. Law, J. W.-F. et al. Streptomyces colonosanans sp. nov., a novel actinobacterium isolated from Malaysia mangrove soil exhibiting antioxidative activity and cytotoxic potential against human colon cancer cell lines. Front. Microbiol. 8, 877, https://doi. org/10.3389/fmicb.2017.00877 (2017).

27. Tiwari, K. \& Gupta, R. K. Diversity and isolation of rare actinomycetes: an overview. Crit. Rev. Microbiol. 39, 256-294, https://doi. org/10.3109/1040841x.2012.709819 (2013).

28. Lee, L.-H. et al. Diversity and antimicrobial activities of actinobacteria isolated from tropical mangrove sediments in Malaysia. Sci. World J. 2014, https://doi.org/10.1155/2014/698178 (2014).

29. Arocha-Garza, H. F., Canales-Del Castillo, R., Eguiarte, L. E., Souza, V. \& De la Torre-Zavala, S. High diversity and suggested endemicity of culturable Actinobacteria in an extremely oligotrophic desert oasis. PeerJ 5, e3247, https://doi.org/10.7717/peerj.3247 (2017).

30. Tan, L. T.-H., Chan, K.-G., Lee, L.-H. \& Goh, B.-H. Streptomyces bacteria as potential probiotics in aquaculture. Front. Microbiol. 7, 79, https://doi.org/10.3389/fmicb.2016.00079 (2016)

31. Azman, A.-S., Othman, I., Velu, S., Chan, S. \& Lee, K.-G. L.-H. Mangrove rare actinobacteria: taxonomy, natural compound, and discovery of bioactivity. Front. Microbiol. 6, 856, https://doi.org/10.3389/fmicb.2015.00856 (2015).

32. Ser, H.-L. et al. Presence of antioxidative agent, Pyrrolo [1, 2-a] pyrazine-1, 4-dione, hexahydro-in newly isolated Streptomyces mangrovisoli sp. nov. Front. Microbiol. 6, https://doi.org/10.3389/fmicb.2015.00854 (2015).

33. Ser, H.-L. et al. Streptomyces malaysiense sp. nov:: a novel Malaysian mangrove soil actinobacterium with antioxidative activity and cytotoxic potential against human cancer cell lines. Sci. Rep. 6, https://doi.org/10.1038/srep24247 (2016).

34. Ashton, E. C. \& Macintosh, D. J. Preliminary assessment of the plant diversity and community ecology of the Sematan mangrove forest, Sarawak, Malaysia. Forest Ecol. Manag. 166, 111-129 (2002).

35. Giri, C. et al. Status and distribution of mangrove forests of the world using earth observation satellite data. Glob. Ecol. Biogeogr. 20, 154-159, https://doi.org/10.1111/j.1466-8238.2010.00584.x (2011).

36. Nobili, S. et al. Natural compounds for cancer treatment and prevention. Pharmacol. Res. 59, 365-378, https://doi.org/10.1016/j. phrs.2009.01.017. (2009).

37. Chinembiri, T., du Plessis, L., Gerber, M., Hamman, J. \& Du Plessis, J. Review of natural compounds for potential skin cancer treatment. Molecules 19,11679-11721, https://doi.org/10.3390/molecules190811679 (2014).

38. Ser, H.-L. et al. Antioxidant and cytotoxic potentials of Streptomyces gilvigriseus MUSC $26^{\mathrm{T}}$ isolated from mangrove soil in Malaysia. Prog. Microbes Mol. Biol. 1, a0000002 (2018).

39. Reuter, S., Gupta, S. C., Chaturvedi, M. M. \& Aggarwal, B. B. Oxidative stress, inflammation, and cancer: how are they linked? Free Radic. Biol. Med. 49, 1603-1616, https://doi.org/10.1016/j.freeradbiomed.2010.09.006 (2010).

40. Leufkens, A. M. et al. Biomarkers of oxidative stress and risk of developing colorectal cancer: a cohort-nested case-control study in the European Prospective Investigation Into Cancer and Nutrition. Am. J. Epidemiol. 175, 653-663, https://doi.org/10.1093/aje/ kwr418 (2012).

41. Tan, L. T. H. et al. Streptomyces sp. MUM273b: A mangrove-derived potential source for antioxidant and UVB radiation protectants. MicrobiologyOpen, e859, https://doi.org/10.1002/mbo3.859 (2019).

42. Rao, K. V. R., Mani, P., Satyanarayana, B. \& Rao, T. R. Purification and structural elucidation of three bioactive compounds isolated from Streptomyces coelicoflavus BC 01 and their biological activity. 3 Biotech 7, 24, https://doi.org/10.1007/s13205-016-0581-9 (2017). 
43. Hu, C. et al. Neoantimycins A and B, two unusual benzamido nine-membered dilactones from marine-derived Streptomyces antibioticus H12-15. Molecules 22, 557, https://doi.org/10.3390/molecules22040557 (2017).

44. Mangamuri, U. et al. Bioactive metabolites produced by Streptomyces cheonanensis VUK-A from Coringa mangrove sediments: isolation, structure elucidation and bioactivity. 3 Biotech 6, 63, https://doi.org/10.1007/s13205-016-0398-6 (2016).

45. Hata, T. et al. Mitomycin C. U.S. Patent and Trademark Office (1972).

46. Waksman, S. A., Katz, E. \& Vining, L. C. Nomenclature of the actinomycins. Proc. Natl. Acad. Sci. 44, 602-612 (1958),

47. Arcamone, F. et al. Adriamycin, 14-hydroxydaimomycin, a new antitumor antibiotic from S. Peucetius var. caesius. Biotechnol. Bioeng. 11, 1101-1110, https://doi.org/10.1002/bit.260110607 (1969).

48. Umezawa, H., Maeda, K., Takeuchi, T. \& Okami, Y. New antibiotics, bleomycin A \& B. J. Antibiot. (1966).

49. Bhattacharya, B. \& Mukherjee, S. Cancer therapy using antibiotics. J. Cancer Ther. 6, 849, https://doi.org/10.4236/jct.2015.610093 (2015).

50. Hameş-Kocabaş, E. E. \& Ataç, U. Isolation strategies of marine-derived actinomycetes from sponge and sediment samples. J Microbiol Methods. 88, 342-347, https://doi.org/10.1016/j.mimet.2012.01.010 (2012).

51. Dilip, C. V., Mulaje, S. \& Mohalkar, R. A review on actinomycetes and their biotechnological application. Int. J. Pharm. Sci. Res. 4, 1730, https://doi.org/10.13040/IJPSR.0975-8232.4(5).1730-42 (2013).

52. Pisano, M. A., Sommer, M. J. \& Lopez, M. M. Application of pretreatments for the isolation of bioactive actinomycetes from marine sediments. Appl. Microbiol. Biotechnol. 25, 285-288, https://doi.org/10.1007/BF00253664 (1986).

53. Takizawa, M., Colwell, R. R. \& Hill, R. T. Isolation and diversity of actinomycetes in the Chesapeake Bay. Appl. Environ. Microbiol. 59, 997-1002 (1993).

54. Jensen, P. R., Dwight, R. \& Fenical, W. Distribution of actinomycetes in near-shore tropical marine sediments. Appl. Environ. Microbiol. 57, 1102-1108 (1991).

55. Qin, S. et al. Isolation, diversity, and antimicrobial activity of rare actinobacteria from medicinal plants of tropical rain forests in Xishuangbanna, China. Appl. Environ. Microbiol. 75, 6176-6186, https://doi.org/10.1128/AEM.01034-09 (2009).

56. Goodfellow, M. \& Cross, T. In The Biology of Actinomycetes (eds Goodfellow, M., Mordarski, M. \& Williams, S. T.) 7-164 (Academic Press, 1984).

57. Kurtböke, D. In Microbial Resources: from Functional Existence in Nature to Applications (ed. Kurtböke, D. I.) 45-76 (Elsevier, 2017).

58. Arasu, M. V., Duraipandiyan, V., Agastian, P. \& Ignacimuthu, S. Antimicrobial activity of Streptomyces spp. ERI-26 recovered from Western Ghats of Tamil Nadu. J. Mycol. Med. 18, 147-153, https://doi.org/10.1016/j.mycmed.2008.07.004 (2008)

59. Lee, J. Y., Lee, J. Y., Jung, H. W. \& Hwang, B. K. Streptomyces koyangensis sp. nov., a novel actinomycete that produces 4-phenyl-3butenoic acid. International Journal of Systematic and Evolutionary Microbiology 55, 257-262 (2005).

60. Arasu, M. V., Duraipandiyan, V. \& Ignacimuthu, S. Antibacterial and antifungal activities of polyketide metabolite from marine Streptomyces sp. AP-123 and its cytotoxic effect. Chemosphere 90, 479-487, https://doi.org/10.1016/j.chemosphere.2012.08.006 (2013).

61. Adinarayana, G. et al. Cytotoxic compounds from the marine actinobacterium Streptomyces corchorusii AUBN 1/7. Russian Journal of Bioorganic Chemistry 32, 295-300 (2006).

62. Sajid, I., Shaaban, K. A. \& Hasnain, S. Identification, isolation and optimization of antifungal metabolites from the Streptomyces malachitofuscus ctf9. Braz. J. Microbiol. 42, 592-604, https://doi.org/10.1590/S1517-838220110002000024 (2011).

63. Anderson, L., Ehrlich, J., Sun, S. H. \& Burkholder, P. Strains of Streptomyces, the sources of azaserine, elaiomycin, griseoviridin, and viridogrisein. Antibiot. Chemother. (Northfield, Ill.) 6, 100 (1956).

64. Pittillo, R. \& Hunt, D. In Antibiotics 481-493 (Berlin, Hidelberg: Springer, 1967).

65. Lee, L.-H. et al. Streptomyces pluripotens sp. nov., a bacteriocin-producing streptomycete that inhibits meticillin-resistant Staphylococcus aureus. Int. J. Syst. Evol. Microbiol. 64, 3297-3306, https://doi.org/10.1099/ijs.0.065045-0 (2014).

66. Ser, H.-L. et al. Evaluation of antioxidative and cytotoxic activities of Streptomyces pluripotens MUSC 137 isolated from mangrove soil in Malaysia. Front. Microbiol. 6, https://doi.org/10.3389/fmicb.2015.01398 (2015).

67. Ser, H.-L. et al. Genome sequence of Streptomyces pluripotens MUSC $135^{\mathrm{T}}$ exhibiting antibacterial and antioxidant activity. Mar. Gen. 24, 281-283, https://doi.org/10.1016/j.margen.2015.09.010 (2015).

68. Prashanthi, K., Suryan, S. \& Varalakshmi, K. N. In vitro anticancer property of yellow pigment from Streptomyces griseoaurantiacus JUACT 01. Braz. Arch. Biol. Technol. 58, 869-876, https://doi.org/10.1590/S1516-89132015060271 (2015).

69. Hu, H. et al. Streptomyces qinglanensis sp. nov., isolated from mangrove sediment. Int. J. Syst. Evol. Microbiol. 62, 596-600, https:// doi.org/10.1099/ijs.0.032201-0 (2012).

70. El-Sayed, M. H., Haroun, B. M. \& El-Sayed, A. F. Isolation and identification of antitumor/antibiotic producing soil Streptomyces (Streptomyces coeruleorubidus strain NSWG-20). J. Pharm. Biomed. Sci. 3, 1-10 (2011).

71. Kim, S. B., Falconer, C., Williams, E. \& Goodfellow, M. Streptomyces thermocarboxydovorans sp. nov. and Streptomyces thermocarboxydus sp. nov., two moderately thermophilic carboxydotrophic species from soil. Int. J. Syst. Evol. Microbiol. 48, 59-68 (1998).

72. Reddy, T. et al. Streptomyces hyderabadensis sp. nov., an actinomycete isolated from soil. Int. J. Syst. Evol. Microbiol. 61, 76-80, https://doi.org/10.1099/ijs.0.020446-0 (2011).

73. Petrosyan, P., García-Varela, M., Luz-Madrigal, A., Huitron, C. \& Flores, M. E. Streptomyces mexicanus sp. nov., a xylanolytic micro-organism isolated from soil. Int. J. Syst. Evol. Microbiol. 53, 269-273 (2003).

74. Balachandran, C. et al. Antimicrobial and cytotoxicity properties of 2, 3-dihydroxy-9, 10-anthraquinone isolated from Streptomyces galbus (ERINLG-127). Appl. Biochem. Biotechnol. 172, 3513-3528, https://doi.org/10.1007/s12010-014-0783-8 (2014).

75. Ye, L. et al. Identification and fermentation optimization of a marine-derived Streptomyces griseorubens with anti-tumor activity. Indian Journal of Marine Sciences 38, 14-21 (2009).

76. Reda, F. M. Kinetic properties of Streptomyces canarius L-Glutaminase and its anticancer efficiency. Braz. J. Microbiol. 46, 957-968, https://doi.org/10.1590/S1517-838246420130847 (2015).

77. Xiao, J. et al. Streptomyces avicenniae sp. nov., a novel actinomycete isolated from the rhizosphere of the mangrove plant Avicennia mariana. International Journal of Systematic and Evolutionary Microbiology 59, 2624-2628, https://doi.org/10.1099/ijs.0.009357-0 (2009).

78. Shrivastava, P., Kumar, R., Yandigeri, M. S., Malviya, N. \& Arora, D. K. Isolation and characterization of streptomycetes with plant growth promoting potential from mangrove ecosystem. Polish J. Microbiol. 64, 339-349, https://doi.org/10.5604/17331331.1185232 (2015).

79. Kannan, R. R. \& Vincent, S. P. Molecular characterization of antagonistic Streptomyces isolated from a mangrove swamp. Asian J Biotechnol 3, 237-245, https://doi.org/10.3923/ajbkr.2011.237.245 (2011).

80. Retnowati, Y., Sembiring, L., Moeljopawiro, S., Djohan, T. S. \& Soetarto, E. S. Diversity of antibiotic-producing actinomycetes in mangrove forest of Torosiaje, Gorontalo, Indonesia. Biodiversitas 18, 1453-1461, https://doi.org/10.13057/biodiv/d180322 (2017).

81. Kunwar, A. \& Priyadarsini, K. Free radicals, oxidative stress and importance of antioxidants in human health. J. Med. Allied Sc. 1, $53(2011)$.

82. Tan, L. T.-H. et al. Antioxidative potential of a Streptomyces sp. MUM292 isolated from mangrove soil. BioMed Res. Int. 2018, https://doi.org/10.1155/2018/4823126 (2018) 
83. Rao, A. V. \& Agarwal, S. Role of antioxidant lycopene in cancer and heart disease. J. Am. Coll. Nutr. 19, 563-569, https://doi.org/1 $0.1080 / 07315724.2000 .10718953(2000)$.

84. Diplock, A. T. Will the 'good fairies' please prove to us that vitamin E lessens human degenerative disease? Free Radic. Res. 27, 511-532 (1997).

85. Tirzitis, G. \& Bartosz, G. Determination of antiradical and antioxidant activity: basic principles and new insights. Acta Biochim. Pol. 57, 139-142 (2010).

86. Gupta, D. Methods for determination of antioxidant capacity: a review. Int. J. Pharm. Sci. Res. 6, 546 (2015).

87. Shalaby, E. A. \& Shanab, S. M. Comparison of DPPH and ABTS assays for determining antioxidant potential of water and methanol extracts of Spirulina platensis. Indian J. Geo-Mar. Sci. 42, 556-564 (2013).

88. Wang, T., Jonsdottir, R. \& Ólafsdóttir, G. Total phenolic compounds, radical scavenging and metal chelation of extracts from Icelandic seaweeds. Food Chem. 116, 240-248, https://doi.org/10.1016/j.foodchem.2009.02.041 (2009).

89. Peskin, A. V. \& Winterbourn, C. C. A microtiter plate assay for superoxide dismutase using a water-soluble tetrazolium salt (WST1). Clin. Chim. Acta 293, 157-166, https://doi.org/10.1016/S0009-8981(99)00246-6 (2000).

90. Balasundram, N., Sundram, K. \& Samman, S. Phenolic compounds in plants and agri-industrial by-products: antioxidant activity, occurrence, and potential uses. Food Chem. 99, 191-203, https://doi.org/10.1016/j.foodchem.2005.07.042 (2006).

91. Rice-Evans, C., Miller, N. \& Paganga, G. Antioxidant properties of phenolic compounds. Trends Plant Sci. 2, 152-159, https://doi. org/10.1016/S1360-1385(97)01018-2 (1997).

92. Wojdyło, A., Oszmiański, J. \& Czemerys, R. Antioxidant activity and phenolic compounds in 32 selected herbs. Food Chem. 105, 940-949, https://doi.org/10.1016/j.foodchem.2007.04.038 (2007).

93. Siegel, R. L. et al. Colorectal cancer statistics, 2017. CA Cancer J. Clin. 67, 177-193, https://doi.org/10.3322/caac.21395 (2017).

94. Tan, L. T.-H. et al. Mangrove derived Streptomyces sp. MUM265 as a potential source of antioxidant and anticolon-cancer agents. BMC Microbiol. 19, 38, https://doi.org/10.1186/s12866-019-1409-7 (2019).

95. Malhotra, V. \& Perry, M. C. Classical chemotherapy: mechanisms, toxicities and the therapeutc window. Cancer Bio. Ther. 2, S2-S4, https://doi.org/10.4161/cbt.199 (2003).

96. Lin-Lee, Y.-C., Tatebe, S., Savaraj, N., Ishikawa, T. \& Kuo, M. T. Differential sensitivities of the MRP gene family and $\gamma$-glutamylcysteine synthetase to prooxidants in human colorectal carcinoma cell lines with different p53 status. Biochem. Pharmacol. 61, 555-563, https://doi.org/10.1016/S0006-2952(00)00592-X (2001).

97. Soussi, T. Handbook of p53 mutation in cell lines. Version 1, 2007, https://www.researchgate.net/publication/238766403_ Handbook_of_p53_mutation_in_cell_lines (2007).

98. Tan, L. T.-H. et al. Investigation of antioxidative and anticancer potentials of Streptomyces sp. MUM256 isolated from Malaysia mangrove soil. Front. Microbiol. 6, https://doi.org/10.3389/fmicb.2015.01316 (2015).

99. Hong, K. et al. Actinomycetes for marine drug discovery isolated from mangrove soils and plants in China. Mar. Drugs 7, 24-44, https://doi.org/10.3390/md7010024 (2009).

100. Lee, L.-H. et al. Molecular characterization of Antarctic actinobacteria and screening for antimicrobial metabolite production. World J. Microbiol. Biotechnol. 28, 2125-2137, https://doi.org/10.1007/s11274-012-1018-1 (2012).

101. Gomez-Escribano, J. P., Alt, S. \& Bibb, M. J. Next generation sequencing of actinobacteria for the discovery of novel natural products. Mar. Drugs 14, 78, https://doi.org/10.3390/md14040078 (2016).

102. Imhoff, J. F., Labes, A. \& Wiese, J. Bio-mining the microbial treasures of the ocean: new natural products. Biotechnol. Adv. 29, 468-482, https://doi.org/10.1016/j.biotechadv.2011.03.001 (2011).

103. Lee, L.-H., Chan, K., Stach, J., Wellington, E. M. \& Goh, B. H. Editorial: the search for biological active agent (s) from actinobacteria. Front. Microbiol. 9, 824, https://doi.org/10.3389/fmicb.2018.00824 (2018).

104. Ser, H.-L. et al. Genome sequence of Streptomyces mangrovisoli MUSC $149^{\mathrm{T}}$ isolated from intertidal sediments. Braz. J. Microbiol. 49, 13-15, https://doi.org/10.1016/j.bjm.2017.01.013 (2018).

105. Ser, H.-L. et al. Genome sequence of Streptomyces antioxidans MUSC $164^{\mathrm{T}}$ isolated from mangrove forest. Prog. Microbes Mol. Biol. 1, a0000001 (2018).

106. Azman, A.-S. et al. Monashia flava gen. nov., sp. nov., an actinobacterium of the family Intrasporangiaceae. International Journal of Systematic and Evolutionary Microbiology 66, 554-561, https://doi.org/10.1099/ijsem.0.000753 (2016).

107. Takahashi, Y., Matsumoto, A., Seino, A., Iwai, Y. \& Omura, S. Rare actinomycetes isolated from desert soils. Actinomycetologica 10, 91-97, https://doi.org/10.3209/saj.10_91 (1996).

108. Zainal, N. et al. Streptomyces humi sp. nov., an actinobacterium isolated from soil of a mangrove forest. Antonie van Leeuwenhoek 109, 467-474, https://doi.org/10.1007/s10482-016-0653-1 (2016)

109. Küster, E. \& Williams, S. Media for the isolation of streptomycetes: starch casein medium. Nature 202, 928-929, https://doi. org/10.1038/202928a0 (1964).

110. Shirling, E. t. \& Gottlieb, D. Methods for characterization of Streptomyces species. Int. J. Syst. Evol. Microbiol. 16, 313-340, https:// doi.org/10.1099/00207713-16-3-313 (1966).

111. Atlas, R. M. Handbook of Microbiological Media. 2nd edn, (CRC press, 1993).

112. Lee, L.-H. et al. Mumia flava gen. nov., sp. nov., an actinobacterium of the family. Nocardioidaceae. Int. J. Syst. Evol. Microbiol. 64, 1461-1467, https://doi.org/10.1099/ijs.0.058701-0 (2014).

113. Thompson, J. D., Gibson, T. J., Plewniak, F., Jeanmougin, F. \& Higgins, D. G. The CLUSTAL_X windows interface: flexible strategies for multiple sequence alignment aided by quality analysis tools. Nucleic Acids Res. 25, 4876-4882, https://doi.org/10.1093/ nar/25.24.4876 (1997)

114. Kimura, M. A simple method for estimating evolutionary rates of base substitutions through comparative studies of nucleotide sequences. J. Mol. Evol. 16, 111-120, https://doi.org/10.1007/BF01731581 (1980).

115. Felsenstein, J. Confidence limits on phylogenies: an approach using the bootstrap. Evol., 783-791, https://doi.org/10.2307/2408678 (1985).

116. Yoon, S.-H. et al. Introducing EzBioCloud: a taxonomically united database of $16 \mathrm{~S}$ rRNA gene sequences and whole-genome assemblies. Int. J. Syst. Evol. Microbiol. 67, 1613-1617, https://doi.org/10.1099/ijsem.0.001755 (2017).

117. Tan, L. T.-H. et al. Streptomyces sp. MUM212 as a source of antioxidants with radical scavenging and metal chelating properties. Front. Pharmacol. 8, https://doi.org/10.3389/fphar.2017.00276 (2017).

\section{Acknowledgements}

This work was financially supported by MOSTI ScienceFund Grant (Project No. 06-02-10-SF0300), External Industry Grants from Biotek Abadi Sdn Bhd (vote no. GBA-808138 and GBA-808813) and BioMerge Sdn Bhd (vote no. GMRG2018-01) awarded to L-HL, Monash Global Asia in the $21^{\text {st }}$ Century (GA21) research grant (GAHW-19-L01 and GA-HW-19-S01) awarded to B-HG, University of Malaya for Research Grants (FRGS: FP0222018A, and HIR Grant no. H-50001-A000027) awarded to K-GC. The funders had no role in study design, data collection and analysis, decision to publish, or preparation of the manuscript. 


\section{Author contributions}

The experiments, data analysis, and manuscript writing were performed by J.W.-F.L., while K.-G.C., Y.-W.H., T.M.K., N.-S.A.M., B.-H.G. and L.-H.L. provided vital guidance, insight and technical support for the completion of the project. L.-H.L. and B.-H.G. founded the research project.

\section{Competing interests}

The authors declare no competing interests.

\section{Additional information}

Correspondence and requests for materials should be addressed to K.-G.C. or B.-H.G. or L.-H.L.

Reprints and permissions information is available at www.nature.com/reprints.

Publisher's note Springer Nature remains neutral with regard to jurisdictional claims in published maps and institutional affiliations.

(c) (i) Open Access This article is licensed under a Creative Commons Attribution 4.0 International License, which permits use, sharing, adaptation, distribution and reproduction in any medium or format, as long as you give appropriate credit to the original author(s) and the source, provide a link to the Creative Commons license, and indicate if changes were made. The images or other third party material in this article are included in the article's Creative Commons license, unless indicated otherwise in a credit line to the material. If material is not included in the article's Creative Commons license and your intended use is not permitted by statutory regulation or exceeds the permitted use, you will need to obtain permission directly from the copyright holder. To view a copy of this license, visit http://creativecommons.org/licenses/by/4.0/.

(C) The Author(s) 2019 